University of Wollongong

Research Online

Faculty of Engineering - Papers (Archive)

Faculty of Engineering and Information

Sciences

$1-1-2012$

\title{
Tension capacity of staggered bolted connections in Cold-Reduced Steel Sheets
}

Lip H. Teh

University of Wollongong, Iteh@uow.edu.au

Drew D. A Clements

University of Wollongong, ddac998@uow.edu.au

Follow this and additional works at: https://ro.uow.edu.au/engpapers

Part of the Engineering Commons

https://ro.uow.edu.au/engpapers/4460

\section{Recommended Citation}

Teh, Lip H. and Clements, Drew D. A: Tension capacity of staggered bolted connections in Cold-Reduced Steel Sheets 2012, 769-776.

https://ro.uow.edu.au/engpapers/4460

Research Online is the open access institutional repository for the University of Wollongong. For further information contact the UOW Library: research-pubs@uow.edu.au 


\title{
Tension Capacity of Staggered Bolted Connections in Cold-Reduced Steel
}

\section{Sheets}

\author{
Lip H. Teh ${ }^{1}$ A.M.ASCE and Drew D. A. Clements ${ }^{2}$
}

\begin{abstract}
:
This paper examines the assumption implicit in Cochrane's formula that stresses are uniformly distributed across the net section of a staggered bolted connection. The assumption was found to be overoptimistic for connections in steel having low ductility, leading to unconservative estimates for the tension capacity if the in-plane shear lag is not accounted for. The reduction factor of 0.9 specified in the North American specification for cold-formed steel structures partially but not wholly addresses the problems inherent in the code equations. This paper points out that the "simplification" of Cochrane's original formula into the standard formula used in steel design codes worldwide can lead to additional design capacity that may not be justified. It proposes an equation that accounts for the in-plane shear lag and incorporates Cochrane's original formula for determining the net section area. The proposed equation is demonstrated through laboratory tests on 74 staggered bolted connection specimens in $1.5 \mathrm{~mm}$ and $3.0 \mathrm{~mm} \mathrm{G} 450$ sheet steel to be more accurate and consistent than the code equations in predicting the net section tension capacity.
\end{abstract}

Subject headings: bolted connections, cold-formed steel, steel plates, tensile strength

Author's keywords: cold-reduced steel sheet, net section tension strength, staggered bolts

\footnotetext{
${ }^{1}$ Lecturer, School of Civil, Mining \& Environmental Engineering, University Of Wollongong, Wollongong, NSW 2500, AUSTRALIA

${ }^{2}$ Honours Student, School of Civil, Mining \& Environmental Engineering, University Of Wollongong, Wollongong, NSW 2500, AUSTRALIA
} 


\section{Introduction}

The net section tension capacity of a staggered bolted connection in cold-formed steel sheet is specified in Supplement No. 2 to the North American Specification for the Design of Coldformed Steel Structural Members 2007 (AISI 2010) and in AS/NZS 4600:2005 Cold-formed Steel Structures (SA/SNZ 2005). The two code equations have the same basic form but for the coefficients and in-plane shear lag factors. The common formula for determining the net area of a staggered bolted connection element is adopted from AISC specifications for structural steel members (AISC 1936, 2010), which was based on the theoretical work of Cochrane (1922) and which has remained the same over the past nine decades.

The North American cold-formed steel design code (AISI 2010) has a reduction factor of 0.9 applied to the net area computed using Cochrane's formula, pursuant to the recommendation of LaBoube \& Yu (1996). More recently, Fox \& Schuster (2010) argued that the reduction factor of 0.9 specified in the code was unnecessary based on their own laboratory test results.

The recommendation of LaBoube \& Yu (1996) was based on the laboratory test results of six specimens only having a uniform gage of $41.3 \mathrm{~mm}$ and a uniform stagger of $12.7 \mathrm{~mm}$ (Holcomb et al. 1995), while the conclusion of Fox \& Schuster (2010) was based on sixty eight specimens having a uniform gage of $35 \mathrm{~mm}$. Each of the specimens tested by Fox \& Schuster (2010) had a stagger that was equal to either the bolt diameter $(12.7 \mathrm{~mm})$ or twice the diameter $(25.4 \mathrm{~mm})$. Their experiment tests therefore involved two staggered configurations only, as the two variables of a staggered path are the gage and the stagger, as evident from Figure 1.

The steel materials used by Fox \& Schuster (2010) appear to be more ductile than some coldreduced sheet steels used in the cold-formed steel construction industry (Hancock 2007), with 
elongation at fracture of $41 \%$ (the base length was not reported) for some $1.6 \mathrm{~mm}$ sheet steel specimens and ratios of tensile strength to yield stress of 1.31 for $6.0 \mathrm{~mm}$ specimens. Material ductility is an important factor affecting the ability of a steel member to redistribute stresses away from stress concentration areas prior to reaching the ultimate limit state.

There is an implicit assumption in Cochrane's formula for determining the net area, that stresses are uniformly distributed across the net section. For a bolted connection in steel sheet with low material ductility, such an assumption is difficult to justify in light of the laboratory test results obtained by Teh \& Gilbert (2012). The finite element analysis results obtained by Epstein \& Gulia (1993) suggest that the formula may be overoptimistic.

Furthermore, Cochrane's formula as given in the steel design codes (termed "Cochrane's standard formula" in this paper) has been derived by neglecting a term in the original formula that Cochrane (1922) considered to be "comparatively small" and ignored for "practical purposes". However, the neglect can result in an additional design capacity of about $10 \%$, as demonstrated through a heuristic example in this paper.

This paper proposes an equation for predicting the net section tension capacity of a staggered bolted connection in cold-reduced steel sheet, based on Cochrane's original formula and the in-plane shear lag factor derived by Teh \& Gilbert (2012). The equation is verified against the laboratory test results of staggered bolted connections in $1.5 \mathrm{~mm}$ and $3.0 \mathrm{~mm}$ G450 steel sheets, which had relatively low material ductility. A total of 78 specimens with 58 different configurations were tested. Most specimens were loaded concentrically (double shear), while some $3.0 \mathrm{~mm}$ specimens were loaded eccentrically (single shear).

\section{Code equations for the tension capacity of a staggered bolted connection}


Clause 5.3.3(5) of AS/NZS 4600:2005 (SA/SNZ 2005) specifies the nominal net section tension capacity of a member with staggered bolt holes to be

$$
P_{p}=F_{u} A_{n}
$$

in which $F_{\mathrm{u}}$ is the material tensile strength, and $A_{\mathrm{n}}$ is the net area of the considered section.

Clause 5.3.1 of AS/NZS 4600:2005 specifies that in determining the net area $A_{\mathrm{n}}$ of a member with staggered bolt holes, the width to be deducted shall be the greater of the deduction for non-staggered holes and

$$
W_{d}=n_{s} d_{h}-\sum \frac{s^{2}}{4 g}
$$

in which $n_{\mathrm{s}}$ is the number of bolts in the considered section (equal to 2 in Figure 1), $d_{\mathrm{h}}$ is the bolt hole diameter, $s$ is the stagger, and $g$ is the gage. Equation (2) is based on the theoretical work of Cochrane (1922) using the equal-stress method, and is termed Cochrane's standard formula in this paper.

For the member with staggered bolt holes depicted in Figure 1, Equation (1) thus becomes

$$
P_{p}=F_{u} t\left[W-\max \left(d_{h}, 2 d_{h}-s^{2} / 4 g\right)\right\rfloor
$$

in which $t$ is the sheet thickness and $W$ is the total width of the member.

The beneficial effect of stagger is fully exploited when the tension capacity of the member can be computed from

$$
P_{p}=F_{u} t\left(W-d_{h}\right)
$$


which implies failure across the unstaggered path.

It can be seen from Equations (3) and (4) that, for the member depicted in Figure 1 with the stagger $s$ set to be three times the bolt hole diameter $d_{\mathrm{h}}$, the beneficial effect of stagger is fully exploited when

$$
g \leq 2.25 d_{h}
$$

On the other hand, if the gage $g$ is set to be three times the bolt hole diameter $d_{\mathrm{h}}$, the beneficial effect of stagger is fully exploited when

$$
s \geq 3.464 d_{h}
$$

It can be seen from Equations (5) and (6) that it is not difficult to fully exploit the stagger effect according to Cochrane's formula. However, there is an implicit assumption in the formula that tensile stresses are uniformly distributed over the net section.

According to Section E5.2 of Supplement No. 2 to the North American Specification for the Design of Cold-formed Steel Structural Members 2007 (AISI 2010), the nominal net section tension capacity of the member depicted in Figure 1 is determined from

$$
P_{p}=F_{u} t 0.9\left(W-2 d_{h}+s^{2} / 4 g\right)
$$

The reduction factor of 0.9 in Equation (7) was proposed by LaBoube \& Yu (1996) to account for the test results of Holcomb et al. (1995), who found the ratios of ultimate test load to predicted failure load given by Equation (3) to range from 0.81 to 0.95 , with a mean of 0.89 . LaBoube \& Yu (1996) suggested that the low ratios of ultimate test load to predicted failure load obtained in their laboratory tests could be attributed to the lack of plastic flow that was available in thin flat sheet, i.e. the lack of material ductility of the tested specimens. 
In any case, it can be seen from Equation (7) that the North American specification (AISI 2010) does not appear to limit the net section tension capacity of the member to that given by Equation (4). For staggered bolted connections with narrow gages that satisfy the requirement that the bolt spacing be at least three times the bolt diameter (and hence the staggers are large), Equation (7) tends to overestimate of the tension capacity (see also Equations 5 and 6).

\section{Cochrane's original formula and shear lag in cold-reduced steel sheets}

Cochrane's standard formula shown in Equation (2) results from the simplification of the original formula

$$
W_{d}=n_{s} d_{h}-\sum \frac{s^{2}}{4 g+2 d_{h}}
$$

Although Cochrane's argument for the simplification of Equation (8) into Equation (2) was justified many decades ago (Cochrane 1922), in the present computer age there is little to be gained by neglecting the term " $2 d_{\mathrm{h}}$ " in Equation (8).

For a connection meeting the requirement that the bolt spacing be at least three times the bolt diameter, the neglect of the term " $2 d_{\mathrm{h}}$ " in Equation (8) can result in overestimation of the net section area by up to $5 \%$. For a connection subject to the requirement that the bolt spacing be at least two and a half times the bolt diameter, as specified in Appendix B of the North American Specification for the Design of Cold-formed Steel Structural Members 2007 (AISI 2007), the neglect can result in an overestimation by some $10 \%$, as shown in the following.

If the member depicted in Figure 1 has $W=55 \mathrm{~mm}, d_{\mathrm{h}}=13 \mathrm{~mm}, g=15 \mathrm{~mm}$, and $s=28 \mathrm{~mm}$, then the net section width (i.e. $W-W_{\mathrm{d}}$ ) computed using Equation (2) will be $42.1 \mathrm{~mm}$, which is $10.4 \%$ greater than the value of $38.1 \mathrm{~mm}$ given by Equation (8). With regard to the 
Australasian code, the net width is limited by the relevant term in Equation (4) to $42.0 \mathrm{~mm}$, which is still $10.2 \%$ greater than that given by Cochrane's original formula. The bolt spacing in this example satisfies the code requirement in Canada (Appendix B - AISI 2007) and Europe (ECS 2005) since it is 2.65 times the nominal bolt diameter of $12 \mathrm{~mm}$.

Teh \& Gilbert (2012) have demonstrated the effect of in-plane shear lag on the net section tension capacity of a bolted connection in cold-reduced steel sheets with low ductility. Based on the in-plane shear lag factor proposed by Teh \& Gilbert (2012) and Cochrane's original formula shown in Equation (8), the tension capacity of the member depicted in Figure 1 should be computed from

$$
P_{p}=\left(0.9+0.1 d_{h} / W\right) F_{u} t\left\lfloor W-\max \left(d_{h}, 2 d_{h}-\frac{s^{2}}{4 g+2 d_{h}}\right)\right\rfloor
$$

\section{Test materials}

The G450 sheet steel materials used in the laboratory tests, which have a trade name GALVASPAN $^{\circledR}$, were manufactured and supplied by Bluescope Steel Port Kembla Steelworks, Australia. Two nominal thicknesses were used in the present work, being $1.5 \mathrm{~mm}$ and $3.0 \mathrm{~mm}$. The average base metal thicknesses $t_{\text {base, }}$ yield stresses $F_{\mathrm{y}}$, tensile strengths $F_{\mathrm{u}}$ and elongations at fracture over $15 \mathrm{~mm}, 25 \mathrm{~mm}$ and $50 \mathrm{~mm}$ gauge lengths $\varepsilon_{15}, \varepsilon_{25}$ and $\varepsilon_{50}$, and uniform elongation outside the fracture $\varepsilon_{\mathrm{uo}}$ of the steel materials as obtained from six $12.5 \mathrm{~mm}$ wide tension coupons are shown in Table 1. Tensile loading of all coupons and bolted connection specimens is in the direction transverse to the rolling direction of the G450 sheet steel. The tension coupon tests were conducted at a constant stroke rate of $1 \mathrm{~mm} / \mathrm{minute}$ resulting in a strain rate of about $2 \times 10^{-4}$ per second prior to necking. 
The G450 sheet steels used in the present work represent the grades of steel covered by AS/NZS 4600 (SA/SNZ 2005) which are among those having the lowest ductility and for which the nominal tensile strength and yield stress may be fully utilised in structural design calculations (Hancock 2007). The use of the present materials therefore represents a stringent verification of the design equations.

\section{Specimen configurations and test arrangements}

The basic configuration of each specimen is depicted in Figure 1. As shown in the figure, each specimen had three staggered bolts, arrayed along two gage lines. The presence of three bolts ensured that bearing failure did not occur. For each sheet thickness, the geometric variables are the sheet width $W$, the gage $g$, the stagger $s$, and the bolt hole diameter $d_{\mathrm{h}}$. Their values for each bolted connection specimen are detailed in the next section, which ensured that block shear failure (Teh \& Clements 2012) did not occur.

There are groups of specimens in which the gage was kept constant while the staggers were varied, groups in which the stagger was kept constant while the gages were varied, groups in which the ratio of stagger to gage was uniform but the staggers (and the gages) were varied, and groups in which both the gage and the stagger were kept constant while the sheet widths were varied. There are however overlapping members between the groups, designed to minimise the total number of specimens.

Two nominal sizes of bolts, being $12 \mathrm{~mm}$ and $16 \mathrm{~mm}$, were used for the connections. The bolt holes were $1 \mathrm{~mm}$ larger than the corresponding nominal bolt diameters. It may be noted that the maximum diameter of a bolt hole for a $12 \mathrm{~mm}$ or larger bolt is restricted to the bolt diameter plus $2 \mathrm{~mm}$ (SA/SNZ 2005) or $1.6 \mathrm{~mm}$ (AISI 2007). The bolts were only tightened by hand, and no washers were used unless indicated otherwise in the next section. 
Most of the specimens were loaded concentrically as double shear connection specimens, as illustrated in Figure 2(a). For the purpose of investigating any noticeable differences in net section tension strength between double shear and single shear staggered bolted connections, some $3.0 \mathrm{~mm}$ specimens were loaded eccentrically, as illustrated in Figure 2(b).

In order to ensure the connected sheets remain vertical throughout the tensile test, a shim plate of the same thickness as the sheet was welded to one of the outer sheets of a double shear specimen at the grip end, as depicted in Figure 2(a). Shim plates were also welded to both sheets of a single shear specimen, as depicted in Figure 2(b). The bolted sheets were gripped in such a way that prevented them from rotating in-plane, as illustrated in Figure 3.

The bolted connection specimens were tested to failure using an Instron 8033 universal testing machine at a stroke rate of $1 \mathrm{~mm} /$ minute, which coincides with that used for the present tension coupon tests. In the vicinity of the ultimate load associated with net section fracture, the elongation of either a bolted connection specimen or a tension coupon is concentrated in the yielded and/or necked region. Therefore, the stroke rate used in determining the ultimate test load $P_{\mathrm{t}}$ of a bolted connection specimen should ideally not be greater than that used in determining the material tensile strength $F_{\mathrm{u}}$, even though the overall length of the former is many times greater. A greater strain rate leads to a higher implied tensile strength (Kassar \& Yu 1992).

\section{Experimental test results and discussions}

In calculating the nominal tension capacity $P_{\mathrm{p}}$ of a specimen predicted by a design equation, the measured values of the geometric dimensions such as the base metal thickness, the overall sheet width, and the bolt hole diameter, are used. However, for ease of comparisons, only the nominal values are shown in the tables following. 


\section{Double shear $3.0 \mathrm{~mm}$ specimens}

Table 2 lists the relevant geometric dimensions and the test results of the double shear connections in $3.0 \mathrm{~mm}$ G450 steel sheet. An empty cell in the table indicates that the data in the above cell applies. The table shows the ratios of the ultimate test load $P_{\mathrm{t}}$ to the tension capacity $P_{\mathrm{p}}$ predicted by Equations (3) and (7), which are specified in the current Australasian and North American cold-formed steel design codes, respectively. It also includes the ratios obtained using the proposed Equation (9).

Table 2 shows that Equation (3) consistently and significantly overestimates the net section tension capacity of the tested specimens. The major reason is the implicit assumption that stresses are uniformly distributed over the net section. The average ratio of the ultimate test load $P_{\mathrm{t}}$ to the net section tension capacity $P_{\mathrm{p}}$ predicted by the equation is 0.92 .

Although Equation (7) yields reasonably accurate results for most specimens in Table 2, it overestimates the capacity of specimen CT22 (numbered 7) by more than $20 \%(1 / 0.81=$ 1.23). The equation also significantly overestimates the capacity of specimens CT42 and CT43 (numbered 20 and 21), which had a gage of $15 \mathrm{~mm}$ but satisfied the requirement that the bolt spacing be at least three times the bolt diameter. These significant overestimations are despite the reduction factor of 0.9 embedded in the equation.

In contrast to Equations (3) and (7), Equation (9) consistently predicts the net section tension capacity of each specimen listed in Table 2 with excellent accuracy.

Figure 5(a) shows that the critical net section of specimen CT18 (numbered 1 in Table 2) cut across the unstaggered path, while Figure 5(b) shows that the critical net section of specimen CT11b (numbered 4) cut across the staggered path. Only the proposed Equation (9) yields accurate predictions for both specimens. 


\section{Single shear $3.0 \mathrm{~mm}$ specimens}

Table 3 lists the relevant geometric dimensions and the test results of the single shear connections in $3.0 \mathrm{~mm} \mathrm{G} 450$ steel sheet (see Figure $4 \mathrm{~b}$ for an example). An empty cell in the table indicates that the data in the above cell applies. Specimens numbered 36 through 45 had washers under both the bolt head and the nut, while the rest did not. The table shows the ratios of the ultimate test load $P_{\mathrm{t}}$ to the tension capacity $P_{\mathrm{p}}$ predicted by Equations (3), (7) and (9).

The bolt heads of specimens numbered 31 and 33 through 35 punched through the bolt holes, as shown Figure 6(a) for specimen numbered 33, resulting in low ratios of the ultimate test load to the predicted net section tension capacity, especially for specimen numbered 35 . Figure 6(b) shows that the use of washers can prevent the bolt head from punching through the bolt hole to achieve the net section fracture mode.

Table 3 shows that, in cases where the specimen failed by pure net section fracture, Equation (9) predicts the net section tension capacity with reasonable accuracy. It is also evident from the range of $P_{\mathrm{t}} / P_{\mathrm{p}}$ values shown in Tables 2 and 3 that separate resistance factors are not required for determining the design net section tension capacities of double and single shear staggered bolted connections in cold-reduced steel sheets.

The failure mode associated with the bolt head punching through the bolt hole should be treated as a distinct strength limit state, predicted using a separate equation.

\section{Double shear $1.5 \mathrm{~mm}$ specimens}

Table 4 lists the relevant geometric dimensions and the test results of the double shear connections in $1.5 \mathrm{~mm} \mathrm{G450} \mathrm{steel} \mathrm{sheet.} \mathrm{An} \mathrm{empty} \mathrm{cell} \mathrm{in} \mathrm{the} \mathrm{table} \mathrm{indicates} \mathrm{that} \mathrm{the} \mathrm{data} \mathrm{in}$ 
the above cell applies. The table shows the ratios of the ultimate test load $P_{\mathrm{t}}$ to the net section tension capacity $P_{\mathrm{p}}$ predicted by Equations (3), (7) and (9).

Table 4 shows that Equations (3) and (7) significantly overestimate the net section tension capacities of some $1.5 \mathrm{~mm}$ specimens. It can also be seen from Tables 4 and 2 that the effect of in-plane shear lag was more pronounced for the $1.5 \mathrm{~mm}$ specimens than for the $3.0 \mathrm{~mm}$ specimens, the latter having greater material ductility as evident from Table 1.

The average ratio of the ultimate test load $P_{\mathrm{t}}$ to the net section tension capacity $P_{\mathrm{p}}$ predicted by Equation (9) for the $1.5 \mathrm{~mm}$ specimens listed in Table 4 is 0.95 , with a standard deviation of 0.033 . These values compare unfavourably against the corresponding values of 1.01 and 0.025 for the double shear $3.0 \mathrm{~mm}$ specimens.

Figure 7(a) shows that the critical net section of specimen CT17a (numbered 46 in Table 4) cut across the unstaggered path, while Figure $7(\mathrm{~b})$ shows that the critical net section of specimen CT29b (numbered 62) cut across the staggered path. Only the proposed Equation (9) yields reasonably accurate predictions for both specimens.

It is also evident from the mean values of $P_{\mathrm{t}} / P_{\mathrm{p}}$ shown in Tables 2 and 4 that the reduction factor of 0.9 in Equation (7) proposed by LaBoube \& Yu (1996) significantly improved the accuracy of the equation in predicting the net section tension capacities of the present specimens. However, Equation (7) results in substantially greater coefficients of variation compared to Equation (9). 


\section{Resistance factor (or capacity reduction factor)}

The overall average ratio of the ultimate test load $P_{\mathrm{t}}$ to the net section tension capacity $P_{\mathrm{p}}$ predicted by Equation (9) for the 74 specimens that failed in net section fracture is 0.98 , with a standard deviation of 0.041 . It therefore seems reasonable to treat these specimens as one population for the purpose of determining a uniform resistance factor to be applied to the proposed equation.

Section F1.1 of the North American specification (AISI 2007) specifies that the resistance factor $\phi$ of a design equation is determined as follows

$$
\phi=C_{\phi}\left(M_{m} F_{m} P_{m}\right) e^{p}
$$

in which $C_{\phi}$ is the calibration coefficient equal to 1.52 in the case of the Load and Resistance Factor Design (LRFD), $M_{\mathrm{m}}$ is the mean value of the material factor equal to 1.187 in the present case, $F_{\mathrm{m}}$ is the mean value of the fabrication factor equal to 0.99 , and $P_{\mathrm{m}}$ is the mean value of the professional factor equal to 0.98 as stated in the first paragraph of this section. The statistical parameters of the material and fabrication factors of the (unwelded) $1.5 \mathrm{~mm}$ and $3.0 \mathrm{~mm}$ G450 sheet steels have been previously provided by Teh \& Hancock (2005).

The power $p$ of the natural logarithmic base $e$ in Equation (10) is

$$
p=-\beta_{0} \sqrt{V_{M}^{2}+V_{F}^{2}+C_{p} V_{P}^{2}+V_{Q}^{2}}
$$

in which the target reliability index $\beta_{0}$ is 3.5 (AISI 2007, SA/SNZ 1998), $V_{\mathrm{M}}$ is the coefficient of variation of the material factor equal to 0.03 in the present case, $V_{\mathrm{F}}$ is the coefficient of variation of the fabrication factor equal to $0.02, V_{\mathrm{P}}$ is the coefficient of variation of the professional factor equal to 0.065 being the minimum value specified in Section F1.1 of the 
specification, $C_{\mathrm{p}}$ is the correction factor equal to 1.04 as computed from the relevant equation given in Section F1.1, and $V_{\mathrm{Q}}$ is the coefficient of variation of load effects equal to 0.21 as specified in Section F1.1.

It was found that in order to achieve the target reliability index $\beta_{0}$ of 3.5 in the LRFD, Equation (10) yields a resistance factor of 0.80 . This value is higher than the current value of 0.65 specified in the cold-formed steel design codes (AISI 2007, SA/SNZ 2005), reflecting the greater reliability of the proposed Equation (9) compared to Equations (3) and (7).

\section{Conclusions}

Cochrane's formula for determining the net section area of a staggered bolted connection implicitly assumes that stresses are uniformly distributed over the net section. This assumption is not justified for connections in cold-reduced steel sheet with low ductility, in which the effect of in-plane shear lag on the net section tension capacity is significant.

The reduction factor of 0.9 specified in the current North American specification for coldformed steel structures goes a long way to account for the in-plane shear lag effect in staggered bolted connections. However, for the connections in which the gage is relatively narrow compared to the stagger, the code equation incorporating the reduction factor still leads to over-optimistic estimates for the net section tension capacity.

For certain configurations, the simplification of Cochrane's original formula into the standard formula used in the steel design codes worldwide leads to overestimations of the net section area by some $10 \%$. There is little to be gained from the trivial simplification. 
The new equation proposed in this paper incorporates the in-plane shear lag factor derived by Teh \& Gilbert (2012) and Cochrane's original formula, leading to more accurate and more consistent results compared to the code equations.

It is proposed that a resistance factor of 0.80 be applied to the new equation in order to ensure a reliability index of not less than 3.5 in the LRFD approach of the North American specification for the design of cold-formed steel structures.

\section{Acknowledgments}

The authors would like to thank John Kralic, Manager, Lysaght Research \& Technology, Bluescope Steel Limited, for supplying the G450 sheet steel materials used in the present work. The authors thank Gregory Hancock, Emeritus Professor, The University of Sydney, for his expert input and for providing crucial references concerning the state-of-the-art of bolted connection design in cold-formed sheet steel. The authors also thank Chris Cook, Dean of Engineering, and Muhammad Hadi, head of the Advanced Structural Engineering and Construction Materials Group, both of the University of Wollongong, for supporting the laboratory tests that were conducted in the High Bay Lab of the Faculty of Engineering. The test specimens were fabricated by Ritchie McLean.

\section{References}

AISC (1936) Specification for the Design, Fabrication and Erection of Structural Steel for Buildings, American Institute of Steel Construction, Chicago IL.

AISC (2010) Specification for Structural Steel Buildings, ANSI/AISC 360-10, American Institute of Steel Construction, Chicago IL.

AISI (2007) North American Specification for the Design of Cold-formed Steel Structural Members 2007 Edition, American Iron and Steel Institute, Washington DC. 
AISI (2010) Supplement No. 2 to the North American Specification for the Design of Coldformed Steel Structural Members 2007 Edition, American Iron and Steel Institute, Washington DC.

Cochrane, V. H. (1922) "Rules for rivet hole deductions in tension members." Engrg. News Record, Vol. 80, November.

ECS (2005) Eurocode 3: Design of steel structures, Part 1.8: Design of joints, EN 1993-1-8, European Committee for Standardisation, Brussels, Belgium.

Epstein, H. I., and Gulia, F. S. (1993) "Finite element studies of bolt stagger effects in tension members." Comput. Struct., 48, 6, 1153-1156.

Fox, D. M., and Schuster, R. M. (2010) "Cold formed steel tension members with two and three staggered bolts," Proc., $20^{\text {th }}$ Int. Specialty Conf. Cold-Formed Steel Structures, St Louis, MO, 575-588.

Hancock, G. J. (2007) Design of Cold-Formed Steel Structures, $4^{\text {th }}$ ed., Australian Steel Institute, Sydney.

Holcomb, R. D., LaBoube, R. A., and Yu, W. W. (1995) “Tensile and bearing capacities of bolted connections," Second Summary Report, Civil Engineering Study 95-1, ColdFormed Steel Series, Department of Civil Engineering, Center for Cold-Formed Steel Structures, University of Missouri-Rolla.

Kassar, M., and Yu, W. W. (1992) "Effect of strain rate on material properties of sheet steels." J. Struct. Eng., 118 (11), 3136-3150.

LaBoube, R. A., and Yu, W. W. (1996) "Additional design considerations for bolted connections," Proc., $13^{\text {th }}$ Int. Specialty Conf. Cold-Formed Steel Structures, St Louis, MO, 575-593.

SA/SNZ (1998). Cold-Formed Steel Structures-Commentary, Supplement to AS/NZS 4600:1996, Standards Australia/Standards New Zealand. 
SA/SNZ (2005) Cold-Formed Steel Structures, AS/NZS 4600:2005, Standards Australia/Standards New Zealand, Sydney, New South Wales.

Teh, L. H., and Clements, D. D. A. (2012) "Block shear capacity of bolted connections in cold-reduced steel sheets," accepted for publication in J. Struct. Eng., ASCE.

Teh, L. H., and Gilbert, B. P. (2012) "Net section tension capacity of bolted connections in cold-reduced steel sheets," accepted for publication in J. Struct. Eng., ASCE.

Teh, L. H., and Hancock, G. J. (2005) "Strength of welded connections in G450 sheet steels." J. Struct. Eng., 131 (10), 1561-1569. 


\section{Notation}

$A_{\mathrm{n}}=$ net area of considered section

$C_{\mathrm{p}}=$ correction factor

$C_{\phi}=$ calibration coefficient

$d \quad=$ bolt diameter

$d_{\mathrm{h}}=$ bolt hole diameter

$g \quad=$ bolt gauge spacing

$F_{\mathrm{m}}=$ mean value of fabrication factor

$F_{\mathrm{u}}=$ tensile strength of steel material

$F_{\mathrm{y}}=$ yield stress of steel material

$M_{\mathrm{m}}=$ mean value of material factor

$P_{\mathrm{m}}=$ mean value of professional factor

$P_{\mathrm{p}}=$ predicted failure load

$s \quad=$ bolt pitch spacing

$t \quad=$ nominal sheet thickness

$t_{\text {base }}=$ base metal thickness

$V_{\mathrm{F}}=$ coefficient of variation of fabrication factor

$V_{\mathrm{M}}=$ coefficient of variation of material factor

$V_{\mathrm{P}}=$ coefficient of variation of professional factor

$V_{\mathrm{Q}}=$ coefficient of variation of load effects

$W=$ sheet width

$\beta_{0}=$ target reliability index

$\varepsilon_{15}=$ elongation at fracture over a gauge length of $15 \mathrm{~mm}$

$\varepsilon_{25}=$ elongation at fracture over a gauge length of $25 \mathrm{~mm}$ 
Journal of Structural Engineering. Submitted May 31, 2011; accepted September 22, 2011; posted ahead of print September 26, 2011. doi:10.1061/(ASCE)ST.1943-541X.0000514

$\varepsilon_{50}=$ elongation at fracture over a gauge length of $50 \mathrm{~mm}$

$\varepsilon_{\mathrm{uo}}=$ uniform elongation outside fracture zone

$\phi \quad=$ resistance factor (or capacity reduction factor) 


\section{Figure Caption List}

Figure 1 Staggered bolt configuration

Figure 2 Test arrangements of specimens

Figure 3 Clamped end of specimen

Figure 4 Some tested specimens

Figure 5 Failure paths of double shear $3.0 \mathrm{~mm}$ specimens

Figure 6 Failure modes with and without washers

Figure 7 Failure paths of double shear $1.5 \mathrm{~mm}$ specimens 
Figure 1

Journal of Structural Engineering. Submitted May 31, 2011; accepted September 22, 2011; posted ahead of print September 26, 2011. doi:10.1061/(ASCE)ST.1943-541X.0000514

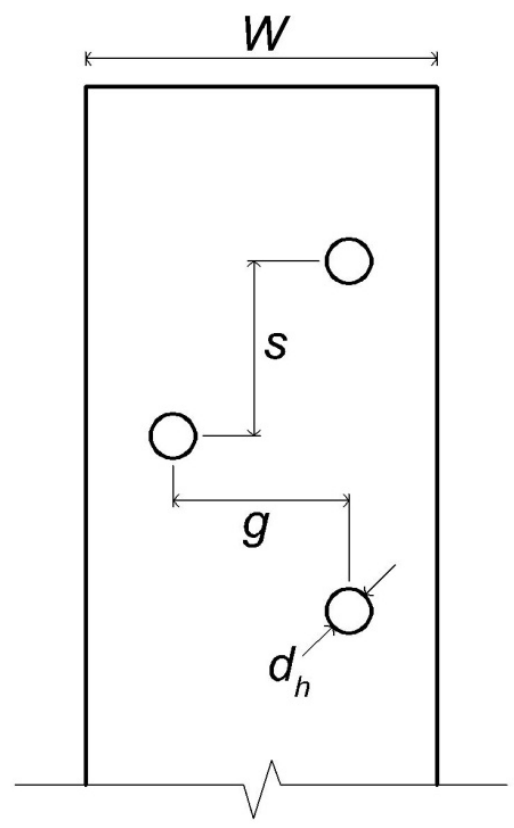

Figure 1 Staggered bolt configuration

\section{Accepted Manuscript Not Copyedited}




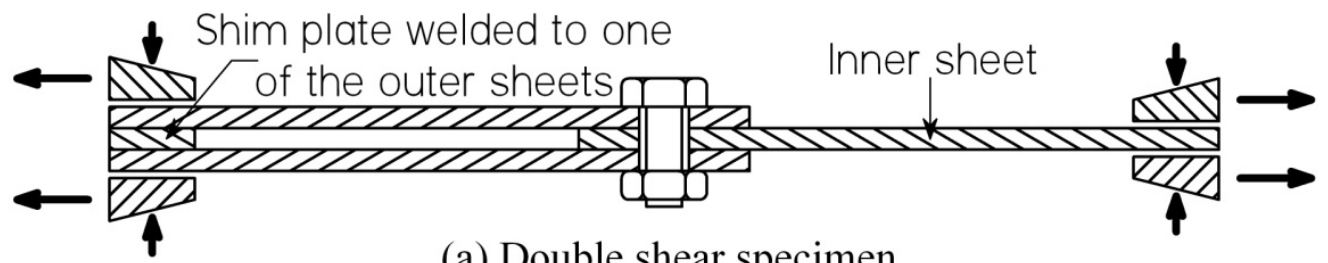

(a) Double shear specimen

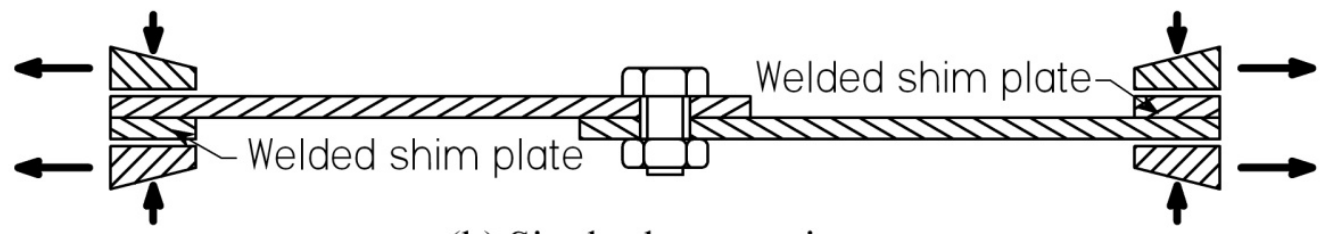

(b) Single shear specimen

Figure 2 Test arrangements of specimens

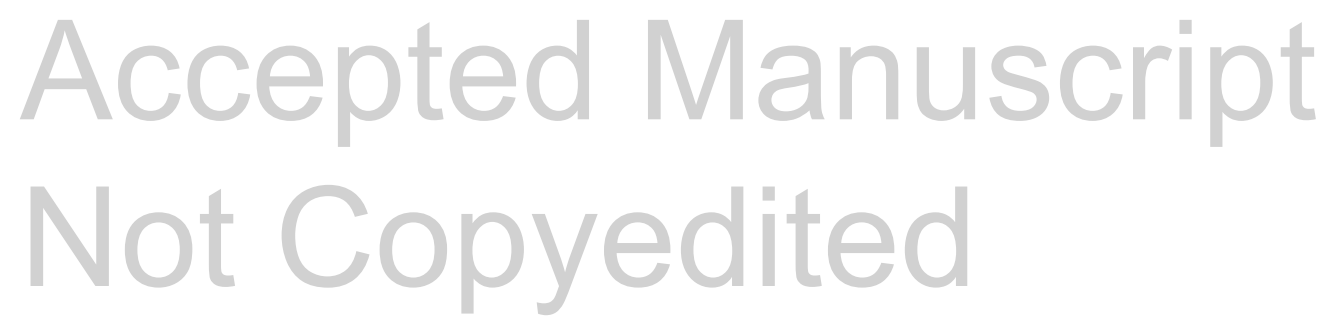


Figure 3

Journal of Structural Engineering. Submitted May 31, 2011; accepted September 22, 2011;

posted ahead of print September 26, 2011. doi:10.1061/(ASCE)ST.1943-541X.0000514

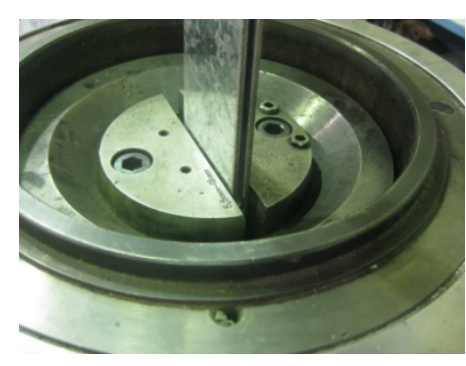

Figure 3 Clamped end of specimen

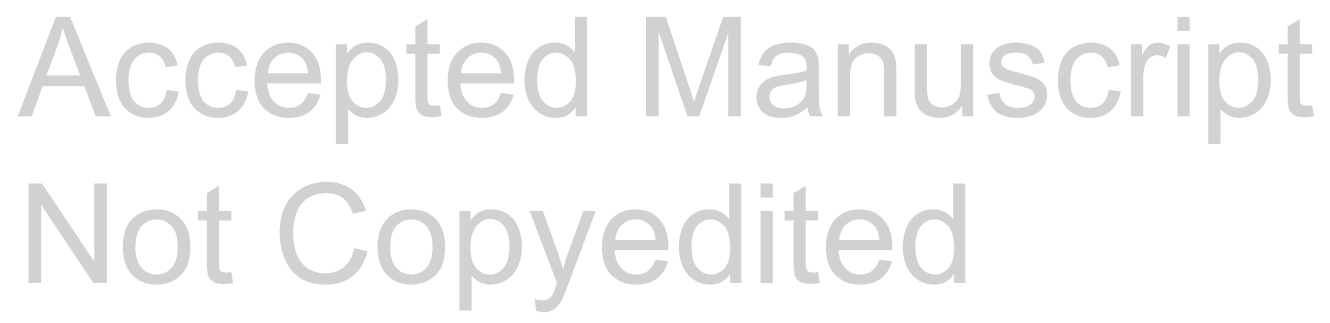


Journal of Structural Engineering. Submitted May 31, 2011; accepted September 22, 2011; posted ahead of print September 26, 2011. doi:10.1061/(ASCE)ST.1943-541X.0000514

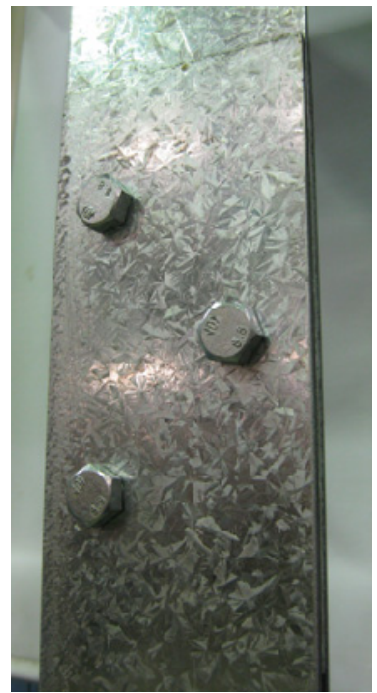

(a) Double shear specimen

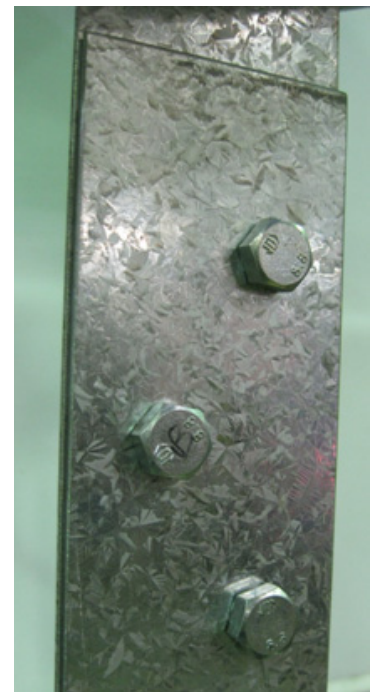

(b) Single shear specimen

Figure 4 Some tested specimens

\section{Accepted Manuscript Not Copyedited}


Figure 5

Journal of Structural Engineering. Submitted May 31, 2011; accepted September 22, 2011; posted ahead of print September 26, 2011. doi:10.1061/(ASCE)ST.1943-541X.0000514
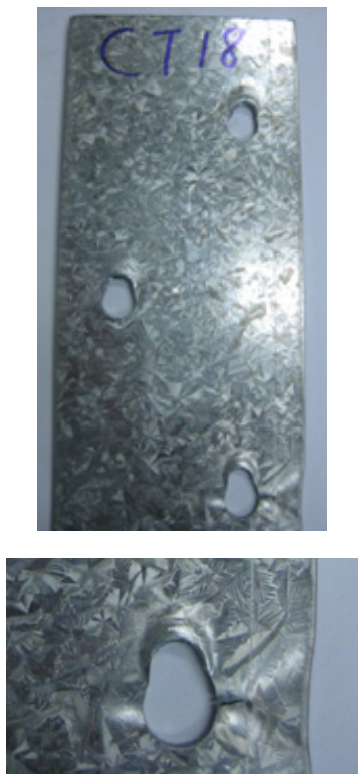

(a) Unstaggered path

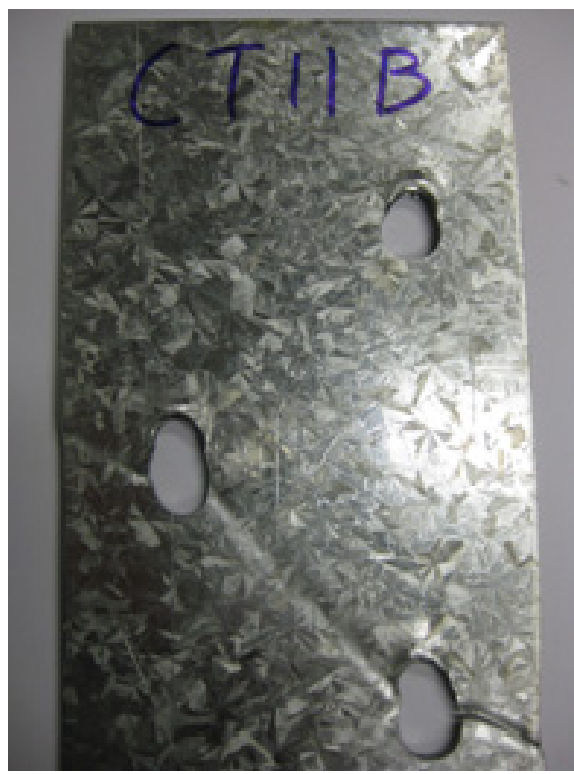

(b) Staggered path

Figure 5 Failure paths of double shear $3.0 \mathrm{~mm}$ specimens

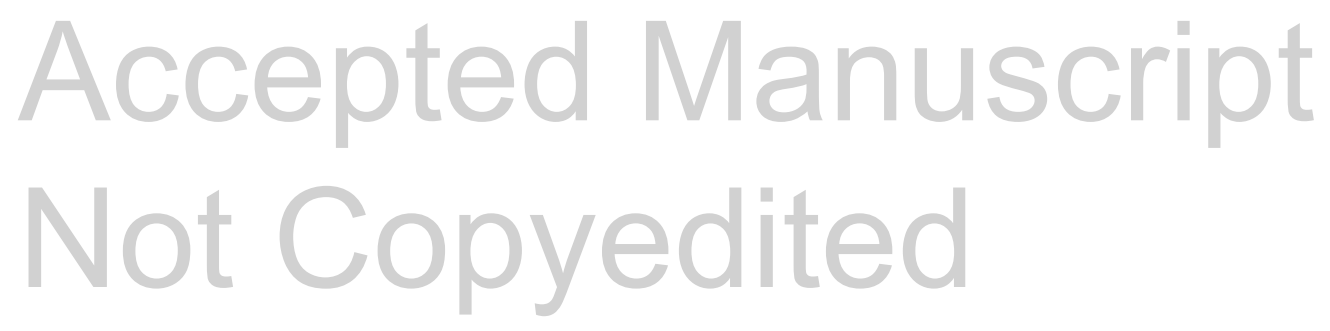


Figure 6

Journal of Structural Engineering. Submitted May 31, 2011; accepted September 22, 2011; posted ahead of print September 26, 2011. doi:10.1061/(ASCE)ST.1943-541X.0000514

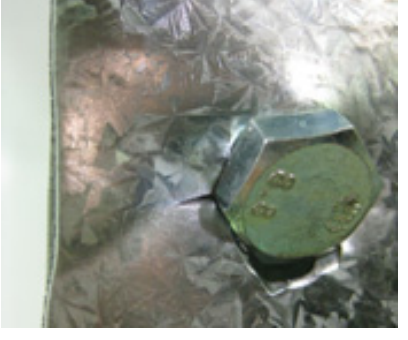

(a) Punching failure

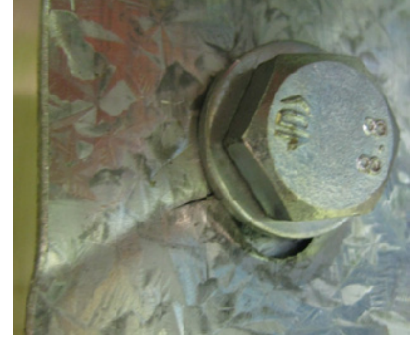

(b) Effect of washer

Figure 6 Failure modes with and without washers

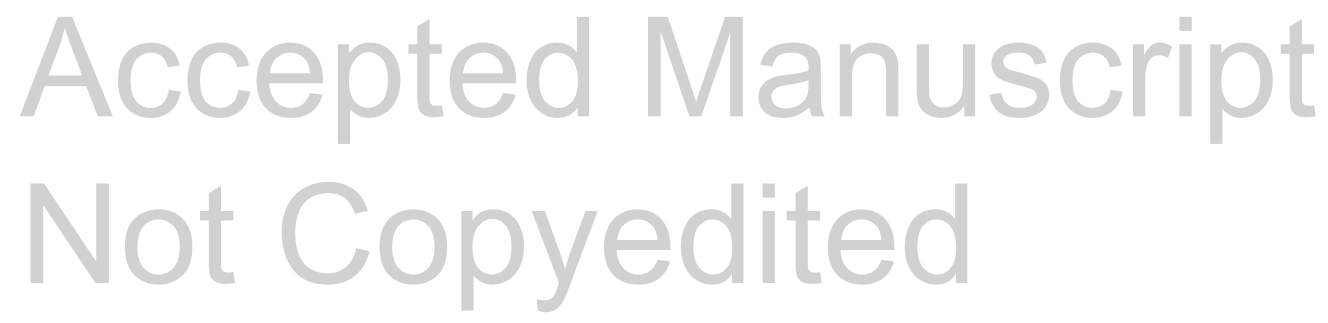




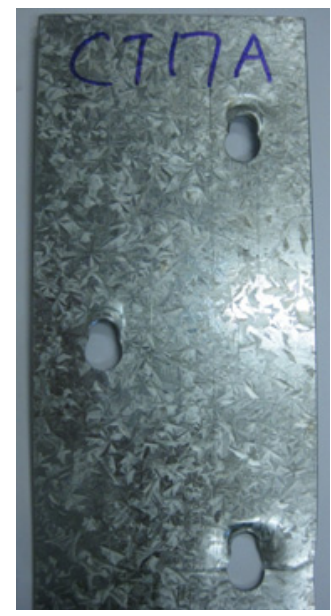

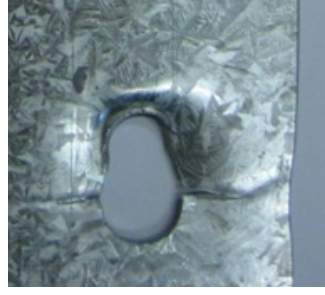

(a) Unstaggered path

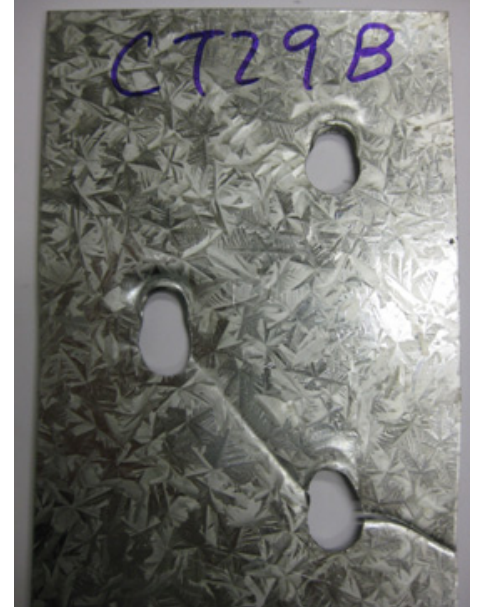

(b) Staggered path

Figure 7 Failure paths of double shear $1.5 \mathrm{~mm}$ specimens

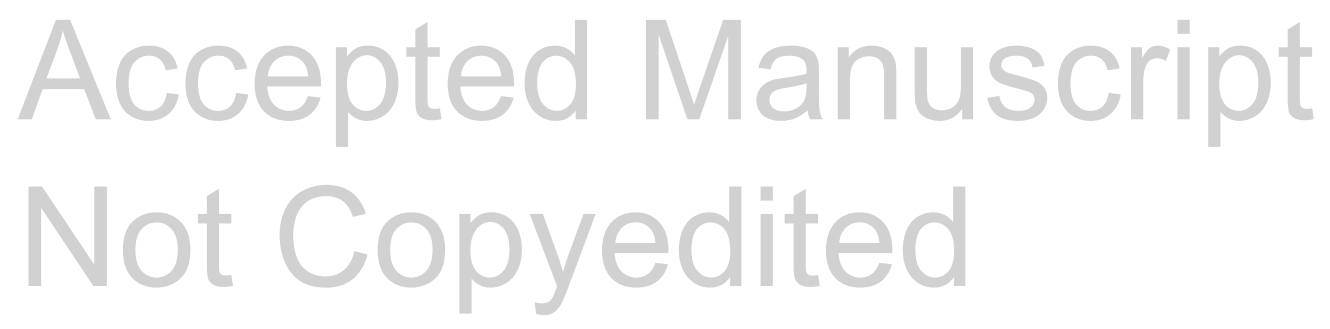


Journal of Structural Engineering. Submitted May 31, 2011; accepted September 22, 2011; posted ahead of print September 26, 2011. doi:10.1061/(ASCE)ST.1943-541X.0000514

Table 1 Average material properties

\begin{tabular}{|c|c|c|c|c|c|c|c|c|}
\hline & $\begin{array}{c}t_{\text {base }} \\
(\mathbf{m m})\end{array}$ & $\begin{array}{c}F_{\mathrm{y}} \\
(\mathbf{M P a})\end{array}$ & $\begin{array}{c}F_{\mathrm{u}} \\
(\mathrm{MPa})\end{array}$ & $F_{\mathbf{u}} / F_{\mathbf{y}}$ & $\begin{array}{l}\varepsilon_{15} \\
(\%)\end{array}$ & $\begin{array}{l}\varepsilon_{25} \\
(\%)\end{array}$ & $\begin{array}{l}\varepsilon_{50} \\
(\%)\end{array}$ & $\begin{array}{l}\varepsilon_{\mathrm{uo}} \\
(\%)\end{array}$ \\
\hline $1.5 \mathrm{~mm}$ & 1.48 & 605 & 630 & 1.04 & 21.3 & 18.0 & 12.0 & 6.8 \\
\hline $3.0 \mathrm{~mm}$ & 2.95 & 530 & 580 & 1.09 & 29.3 & 22.0 & 15.3 & 8.1 \\
\hline
\end{tabular}

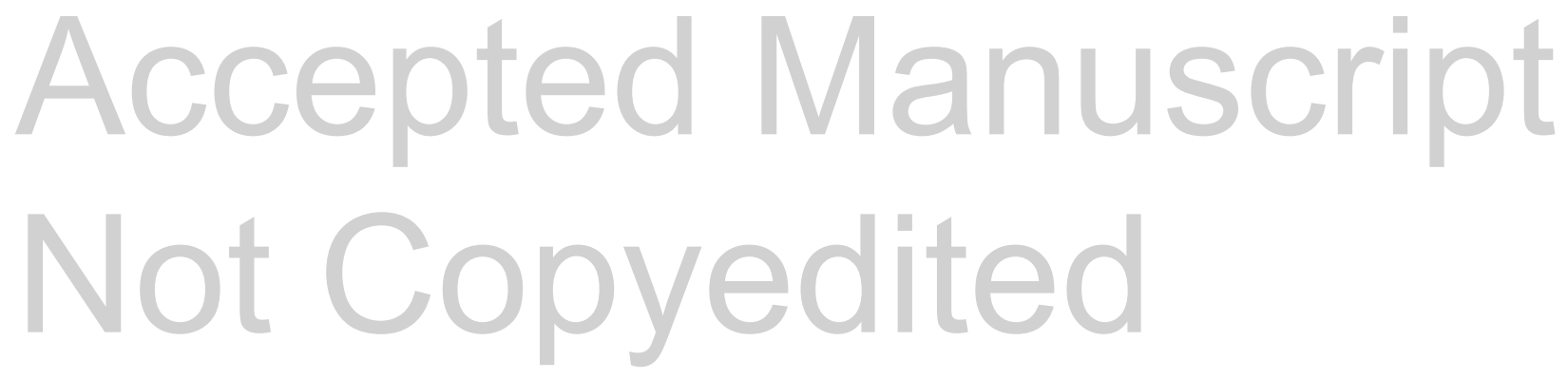


Table 2 Results of double shear bolted connections in $3.0 \mathrm{~mm} \mathrm{G450} \mathrm{steel} \mathrm{sheet}$

\begin{tabular}{|c|c|c|c|c|c|c|c|c|c|}
\hline \multirow{2}{*}{ No. } & \multirow{2}{*}{ Label } & \multirow{2}{*}{$\begin{array}{c}W \\
(\mathrm{~mm})\end{array}$} & \multirow{2}{*}{$\begin{array}{c}d_{\mathrm{h}} \\
(\mathrm{mm})\end{array}$} & \multirow{2}{*}{$\begin{array}{c}g \\
(\mathrm{~mm})\end{array}$} & \multirow{2}{*}{$\begin{array}{c}S \\
(\mathbf{m m})\end{array}$} & \multirow{2}{*}{$\begin{array}{c}P_{\mathbf{t}} \\
(\mathbf{k N})\end{array}$} & \multicolumn{3}{|c|}{$\boldsymbol{P}_{\mathrm{t}} / \boldsymbol{P}_{\mathrm{p}}$} \\
\hline & & & & & & & (3) & (7) & (9) \\
\hline 1 & CT18 & 100 & 13 & 50 & 75 & 136.1 & 0.92 & 0.87 & 1.01 \\
\hline 2 & CT16 & & & & 60 & 134.8 & 0.90 & 0.95 & 0.99 \\
\hline 3 & CT11a & & & & 50 & 132.6 & 0.88 & 0.98 & 0.98 \\
\hline 4 & CT11b & & & & 50 & 133.4 & 0.91 & 1.01 & 1.01 \\
\hline 5 & CT14 & & & & 40 & 120.5 & 0.86 & 0.96 & 0.96 \\
\hline 6 & СТ20 & & & & 25 & 120.2 & 0.92 & 1.02 & 1.01 \\
\hline 7 & СТ22 & & & 40 & 80 & 141.2 & 0.95 & 0.81 & 1.04 \\
\hline 8 & СТ24 & & & & 60 & 137.9 & 0.93 & 0.93 & 1.02 \\
\hline 9 & СТ26 & & & & 50 & 136.7 & 0.92 & 0.99 & 1.01 \\
\hline 10 & СТ28 & & & & 45 & 136.2 & 0.92 & 1.02 & 1.03 \\
\hline 11 & СТ30 & & & & 40 & 132.7 & 0.92 & 1.02 & 1.03 \\
\hline 12 & СТ32 & & & & 30 & 124.7 & 0.92 & 1.02 & 1.02 \\
\hline 13 & СТ34 & & & & 20 & 122.5 & 0.93 & 1.03 & 1.02 \\
\hline 14 & СТ36 & & & & 10 & 120.8 & 0.96 & 1.07 & 1.05 \\
\hline 15 & CT37 & & & 30 & 50 & 135.6 & 0.92 & 0.94 & 1.01 \\
\hline 16 & CT38 & & & & 45 & 136.3 & 0.92 & 0.98 & 1.01 \\
\hline 17 & СТ39 & & & & 30 & 126.7 & 0.91 & 1.01 & 1.02 \\
\hline 18 & CT40 & & & & 22.5 & 126.7 & 0.95 & 1.05 & 1.05 \\
\hline 19 & CT41 & & & & 15 & 121.2 & 0.94 & 1.04 & 1.03 \\
\hline 20 & CT42 & 75 & 13 & 15 & 37.5 & 103.1 & 0.96 & 0.91 & 1.04 \\
\hline 21 & CT43 & & & & 40 & 103.2 & 0.96 & 0.88 & 1.05 \\
\hline 22 & CT3 & 80 & 13 & 30 & 50 & 107.2 & 0.93 & 0.93 & 1.02 \\
\hline 23 & CT4 & & 17 & & & 96.8 & 0.88 & 0.94 & 0.98 \\
\hline 24 & CT7 & 90 & 13 & 40 & & 120.6 & 0.90 & 0.97 & 0.98 \\
\hline 25 & СТ8 & & 17 & & & 109.8 & 0.87 & 0.97 & 0.99 \\
\hline \multirow[t]{3}{*}{26} & CT12 & 100 & 17 & 50 & & 125.7 & 0.93 & 1.04 & 1.04 \\
\hline & & & & & & Mean & 0.92 & 0.97 & 1.01 \\
\hline & & & & & & COV & 0.028 & 0.064 & 0.025 \\
\hline
\end{tabular}


Table 3 Results of single shear bolted connections in $3.0 \mathrm{~mm} \mathrm{G} 450$ steel sheet

\begin{tabular}{|c|c|c|c|c|c|c|c|c|c|c|}
\hline \multirow{2}{*}{ No. } & \multirow{2}{*}{ Label } & \multirow{2}{*}{$\begin{array}{c}W \\
(\mathbf{m m})\end{array}$} & \multirow{2}{*}{$\begin{array}{c}d_{\mathrm{h}} \\
(\mathbf{m m})\end{array}$} & \multirow{2}{*}{$\underset{(\mathbf{m m})}{g}$} & \multirow{2}{*}{$\begin{array}{c}S \\
(\mathbf{m m})\end{array}$} & \multirow{2}{*}{ Washer } & \multirow{2}{*}{$\begin{array}{c}P_{t} \\
(k N)\end{array}$} & \multicolumn{3}{|c|}{$\boldsymbol{P}_{\mathrm{t}} / \boldsymbol{P}_{\mathrm{p}}$} \\
\hline & & & & & & & & (3) & (7) & (9) \\
\hline 27 & ET1 & 80 & 13 & 30 & 50 & No & 104.3 & 0.89 & 0.89 & 0.97 \\
\hline 28 & ET2 & & 17 & & & & 98.4 & 0.90 & 0.94 & 0.99 \\
\hline 29 & ET3 & 90 & 13 & 40 & & & 114.4 & 0.86 & 0.92 & 0.94 \\
\hline 30 & ET4 & & 17 & & & & 110.8 & 0.89 & 0.99 & 1.01 \\
\hline 31 & ET5a & 100 & 13 & 50 & & & 123.7 & $(0.83)^{*}$ & $(0.92)^{*}$ & $(0.92)^{*}$ \\
\hline 32 & ET6 & & 17 & & & & 124.7 & 0.92 & 1.02 & 1.02 \\
\hline 33 & ET12 & & 13 & 40 & 45 & & 121.2 & $(0.82)^{*}$ & $(0.91)^{*}$ & $(0.92)^{*}$ \\
\hline 34 & ET14 & & & & 30 & & 112.7 & $(0.83)^{*}$ & $(0.92)^{*}$ & $(0.92)^{*}$ \\
\hline 35 & ET16 & & & & 10 & & 97.1 & $(0.76)^{*}$ & $(0.85)^{*}$ & $(0.84)^{*}$ \\
\hline 36 & ET8 & 100 & 13 & 50 & 60 & Yes & 128.5 & 0.87 & 0.91 & 0.95 \\
\hline 37 & ET5b & & & & 50 & & 126.6 & 0.86 & 0.95 & 0.96 \\
\hline 38 & ET7 & & & & 40 & & 122.6 & 0.88 & 0.98 & 0.97 \\
\hline 39 & ET9 & & & & 25 & & 114.0 & 0.87 & 0.91 & 0.96 \\
\hline 40 & ET10 & & & 40 & 60 & & 139.8 & 0.87 & 0.97 & 1.03 \\
\hline 41 & ET11 & & & & 50 & & 134.6 & 0.94 & 0.94 & 0.99 \\
\hline 42 & ET13 & & & & 40 & & 125.7 & 0.90 & 0.98 & 0.98 \\
\hline 43 & ET15 & & & & 20 & & 120.9 & 0.88 & 0.98 & 1.02 \\
\hline 44 & ET17 & & & 30 & 45 & & 139.1 & 0.92 & 1.02 & 1.02 \\
\hline 45 & ET18 & & & & 30 & & 120.7 & 0.93 & 0.99 & 0.97 \\
\hline
\end{tabular}

*The bolt heads punched through the bolt holes.

\section{Accepted Manuscript Not Copyedited}


Table 4 Results of double shear bolted connections in $1.5 \mathrm{~mm} \mathrm{G450} \mathrm{steel} \mathrm{sheet}$

\begin{tabular}{|c|c|c|c|c|c|c|c|c|c|}
\hline \multirow{2}{*}{ No. } & \multirow{2}{*}{ Label } & \multirow{2}{*}{$\begin{array}{c}W \\
(\mathbf{m m})\end{array}$} & \multirow{2}{*}{$\begin{array}{c}d_{\mathrm{h}} \\
(\mathbf{m m})\end{array}$} & \multirow{2}{*}{$\underset{(\mathbf{m m})}{g}$} & \multirow{2}{*}{$\begin{array}{c}s \\
(\mathbf{m m})\end{array}$} & \multirow{2}{*}{$\begin{array}{c}P_{\mathrm{t}} \\
(\mathrm{kN})\end{array}$} & \multicolumn{3}{|c|}{$\boldsymbol{P}_{\mathrm{t}} / \boldsymbol{P}_{\mathrm{p}}$} \\
\hline & & & & & & & (3) & (7) & (9) \\
\hline 46 & $\mathrm{CT} 17 \mathrm{a}$ & 100 & 13 & 50 & 75 & 72.0 & 0.89 & 0.84 & 0.98 \\
\hline 47 & CT15a & & & & 60 & 68.5 & 0.84 & 0.89 & 0.92 \\
\hline 48 & $\mathrm{CT} 15 \mathrm{~b}$ & & & & & 69.5 & 0.85 & 0.90 & 0.94 \\
\hline 49 & СТ9c & & & & 50 & 63.2 & 0.79 & 0.87 & 0.88 \\
\hline 50 & СТ9d & & & & & 65.7 & 0.82 & 0.91 & 0.91 \\
\hline 51 & CT13a & & & & 40 & 63.8 & 0.84 & 0.93 & 0.93 \\
\hline 52 & $\mathrm{CT} 13 \mathrm{~b}$ & & & & & 64.0 & 0.84 & 0.93 & 0.93 \\
\hline 53 & CT19a & & & & 25 & 62.7 & 0.88 & 0.97 & 0.96 \\
\hline 54 & CT21a & & & 40 & 80 & 74.3 & 0.92 & 0.78 & 1.01 \\
\hline 55 & $\mathrm{CT} 21 \mathrm{~b}$ & & & & & 72.5 & 0.90 & 0.76 & 0.98 \\
\hline 56 & СТ23a & & & & 60 & 73.6 & 0.91 & 0.91 & 0.99 \\
\hline 57 & $\mathrm{CT} 23 \mathrm{~b}$ & & & & & 73.2 & 0.91 & 0.91 & 0.99 \\
\hline 58 & CT25a & & & & 50 & 69.5 & 0.85 & 0.92 & 0.93 \\
\hline 59 & $\mathrm{CT} 25 \mathrm{~b}$ & & & & & 64.6 & 0.80 & 0.86 & 0.87 \\
\hline 60 & $\mathrm{CT} 27 \mathrm{~b}$ & & & & 45 & 66.6 & 0.83 & 0.92 & 0.92 \\
\hline 61 & CT29a & & & & 40 & 66.2 & 0.85 & 0.94 & 0.95 \\
\hline 62 & CT29b & & & & & 66.0 & 0.85 & 0.94 & 0.94 \\
\hline 63 & CT31a & & & & 30 & 63.9 & 0.87 & 0.97 & 0.96 \\
\hline 64 & CT31b & & & & & 63.2 & 0.85 & 0.94 & 0.94 \\
\hline 65 & СТ33а & & & & 20 & 63.8 & 0.90 & 1.00 & 0.99 \\
\hline 66 & CT33b & & & & & 63.6 & 0.89 & 0.99 & 0.98 \\
\hline 67 & СТ35a & & & & 10 & 62.6 & 0.91 & 1.01 & 1.00 \\
\hline 68 & CT35b & & & & & 61.0 & 0.88 & 0.98 & 0.97 \\
\hline 69 & CT1a & 80 & 13 & 30 & 50 & 54.2 & 0.86 & 0.86 & 0.94 \\
\hline 70 & $\mathrm{CT} 1 \mathrm{~b}$ & & & & & 54.7 & 0.87 & 0.87 & 0.95 \\
\hline 71 & CT2a & & 17 & & & 53.1 & 0.88 & 0.94 & 0.98 \\
\hline 72 & CT2b & & & & & 50.8 & 0.86 & 0.90 & 0.95 \\
\hline 73 & CT5a & 90 & 13 & 40 & & 61.5 & 0.84 & 0.91 & 0.92 \\
\hline 74 & CT5b & & & & & 61.4 & 0.84 & 0.91 & 0.92 \\
\hline 75 & CT6a & & 17 & & & 58.3 & 0.87 & 0.97 & 0.99 \\
\hline 76 & CT6b & & & & & 58.1 & 0.86 & 0.96 & 0.97 \\
\hline 77 & CT10a & 100 & 17 & 50 & & 64.4 & 0.88 & 0.98 & 0.98 \\
\hline \multirow[t]{3}{*}{78} & $\mathrm{CT} 10 \mathrm{~b}$ & & & & & 61.7 & 0.83 & 0.93 & 0.93 \\
\hline & & & & & & Mean & 0.86 & 0.92 & 0.95 \\
\hline & & & & & & $\mathrm{COV}$ & 0.037 & 0.062 & 0.035 \\
\hline
\end{tabular}

